\title{
USING TAGUCHI'S CONTRIBUTION RATIO AND PARETO DIAGRAM IN IDENTIFICATION OF INFLUENTIAL FACTORS IN EXPERIMENTS: CASE STUDIES
}

UDC: 72.01

Original Scientific Paper

\section{Zorica A. VELJKOVIĆ ${ }^{1}$, Vesna K. SPASOJEVIĆ BRKIĆ ${ }^{1}$, Damir ĆURIĆ ${ }^{2}$, Slobodan LJ. RADOJEVIĆ ${ }^{1}$}

${ }^{1}$ Faculty of Mechanical Engineering, University of Belgrade, Serbia

E-mail: vspasojevic@mas.bg.ac.rs

${ }^{2}$ Faculty of Mechanical Engineering, University of Zenica, Bosnia and Herzegovina

Paper received: 01.11.2018.; Paper accepted: 10.12.2018.

\begin{abstract}
This paper considers the usage of Taguchi's contribution ratio as well as an adjusted Pareto diagram for determining the size of influential design factors in experimental design on output values in order to determine the best combination of input factors, as well as factors that can determine output. Two case studies that cover extreme examples are presented in that aim. The first case study examines one input workspace design distributed on tree experimental designs defining space coordinates. Every design has several output values that were measured. The second case study presents two experiments regarding injection of plastic molding process, with same input factors at parts which are different in material and dimensions with geometric deformations as output. It was shown that different experiments lead to different results, of which one is acceptable, while other is useless for further examinations. Accordingly, this paper gives guidelines how to use Taguchi's contribution ratio and Pareto diagram effectively in determination of influential factors in experiments.
\end{abstract}

Keywords: Design of experiments, Taguchi's orthogonal arrays, contribution ratio, Pareto diagram, Crane cabin space, Plastic injection molding.

\section{INTRODUCTION}

Although contribution ratio is in use as in post analysis of experimental results in order to achieve and explanation of optimal results, (Abdallah, Soo, \& Hood, 2018; Bharath, \& Manjunatha, 2018; Gunes, Manay, Senyigit, \& Oyceyhan, 2011; Günay, \& Yücel, 2013; Turgut, Çakmak, \& Y1ld1z, 2012; Vijian, \& Arunachalam, 2007), most researches that use Taguchi method post analyses conduct with $\mathrm{S} / \mathrm{N}$ ratios. Therefore it is not uncommon to combine $\mathrm{S} / \mathrm{N}$ ratio analysis and Pareto diagrams, (Derdour, Kezzar, Bennis, \& Khochmane, 2018; Fratila and Caizar 2011; Ghani, Choudhury, \& Hassan, 2004; Islam, Rafai, \& Subramanian, 2010; Kurra, Swetha, Vinodh Reddy, \& Regalla, 2018; Sarkar, Mitra, \& Bhattacharyya, 2005; Vankanti, \& Ganta, 2014).
This paper presents post experimental analysis of Taguchi's experimental design which uses contribution ratios and modified Pareto analysis in two different case studies. This analysis is explained using two case studies from real experiments, one for the study that is conducted in order to determine optimal work space, (Spasojević-Brkić, Veljković, Golubović, Brkić, \& Kosić-Štić, 2016), while the second case study refers to identification of geometric deformations on parts in plastic injection molding production process of optical fiber hub, (Ćurić, Veljković, \& Duhovnik, 2012; Veljković, Ćurić, \& Radojević 2018; Veljković, Ćurić, Spasojević-Brikić, \& Radojević, 2017). Therefore, after introduction, methodology is going to be presented, and after that the case studies will be described. Based on presented case studies, discussion and conclusions sections are given. 


\section{METHODOLOGY}

This paper discusses interpretation of experimental designs using Taguchi method in two different case studies. Results of the experiments were presented using contribution ratio. Contribution ratio is defined as a relation variations between factorial effect (main factor or interaction) and overall variation expressed in percents, i.e. (Taguchi, 1991):

$$
\rho_{i}=\frac{S S_{F E}}{S S_{T}} \cdot 100(\%)
$$

where $\rho_{i}$ is contribution ratio, $S S_{F E}$ is variation which represents a consequence of factorial effect, while $S S_{T}$ presents overall variation in the experiment.

First case study refers to one of the three experiments conducted in order to determine optimal work space, (Spasojević-Brkić et al., 2016). In those experiments orthogonal arrays are used as full factorial designs. In this study two different results measured from the same experiment were discussed. In the second case study, two different fractional factorial designs using Taguchi's orthogonal arrays were the same factors examined in two different parts of optical fiber hub, using two orthogonal arrays and Taguchi's experimental design with second order errors, (Ćurić et al., 2012; Veljković et al., 2018; Veljković et al., 2017).

As a visual presentation adjusted or modified Pareto diagram was used. Adjustment is referred in positioning errors on the last place in diagram, regardless its values. It was done in order to extract influence of the factors in order to enable their impact and to choose optimal solution for the problem. Error could be presented in standard Pareto diagram only in the chases where outer orthogonal arrays exists and Signal-to-noise ratios are calculated, (Taguchi, 1991).

\section{CASE STUDIES}

\section{Case study 1: Crane cabins optimal workspace design}

In the first presented case study optimal workspace for crane operators was examined using three experiments with Taguchi's orthogonal arrays transformed at traditional design of experiment matrix at two levels. That enabled the examination of three dimensional crane operator workspace (Figures 1a and 1b), (Spasojević-Brkić et al., 2016).

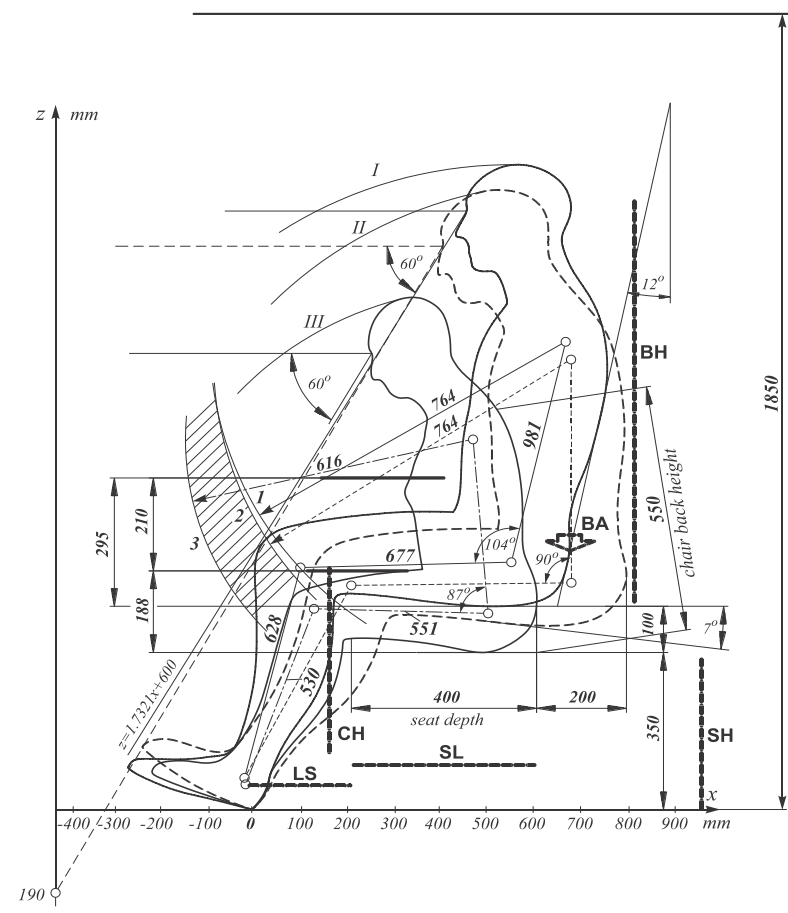

(a)

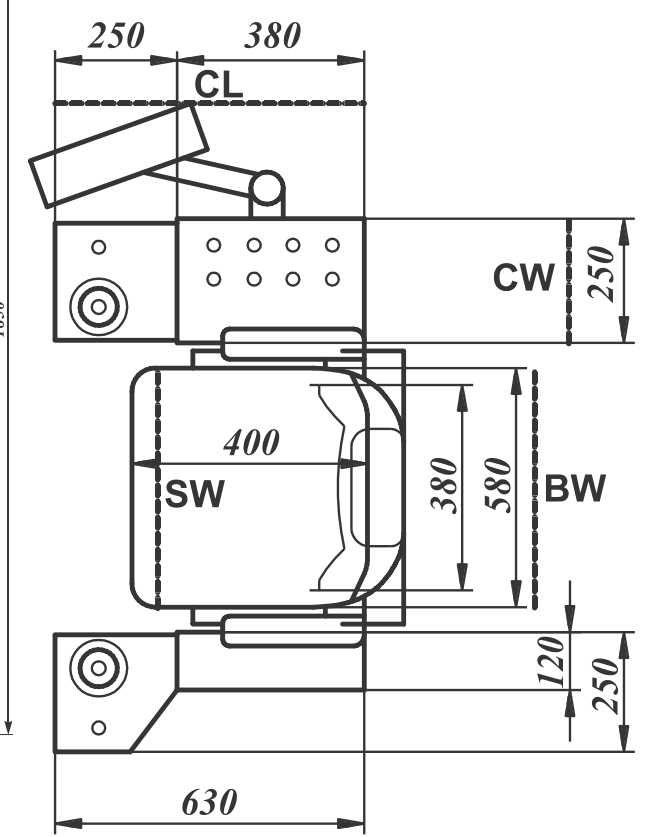

(b)

Figure 1: Main factorial effects shown in the cabin (a) $x$-z plane (b) $x$-y plane Source: Spasojević-Brkić et al., 2016 
First experiment - E1 is $\mathrm{L}_{16}$ orthogonal array which is used as a full factorial design that includes four factors and their interactions - seat length, sitting length, seat width and seat high, labeled as $A, B, C$, and $D$. Output results are measured at two randomly selected crane operators including the following measurement height, leg length, lower leg length, upper leg length, hip width and BMI. The second and the third experiments E2 and E3 contain three factors using $\mathrm{L}_{8}$ orthogonal array as a full factorial design with examined factors for E2 $F, G$ and $H$ - backrest angle, control panel length and backrest height, with output measures for the observed operators height, torso length, shoulder width, arm length and arm reach. The experiment E3 includes factors $J, K$ and $L$ - control panel width, backrest width and control panel length, for which are measured height, hip width, torso length, shoulder width, arm length, arm reach and BMI.

In this paper only two outputs that represent completely opposite results from the first experiment i.e. E1 are examined, height and hip breadth. The results are examined using contribution ratios in order to determine the most influential factors for crane cabin operators` workspace which further can be used for better design of that space. Table 1 presents contribution ratios obtained for leg length in declining order. Corresponding modified Pareto diagram is shown at Figure 2.

Table 1: Contribution ratios for leg length

\begin{tabular}{|c|c|c|c|}
\hline Effect & $\rho(\%)$ & Effect & $\rho(\%)$ \\
\hline$D$ & 81.32 & $B D$ & 0.08 \\
\hline$C$ & 10.29 & $A B$ & 0.06 \\
\hline$B$ & 3.70 & $A B C$ & 0.06 \\
\hline$B C D$ & 1.56 & $A B D$ & 0.06 \\
\hline$A$ & 0.93 & $A B C D$ & 0.05 \\
\hline$A C D$ & 0.73 & $A C$ & 0.01 \\
\hline$C D$ & 0.29 & $A D$ & 0.01 \\
\hline$B C$ & 0.08 & $e$ & 0.78 \\
\hline
\end{tabular}

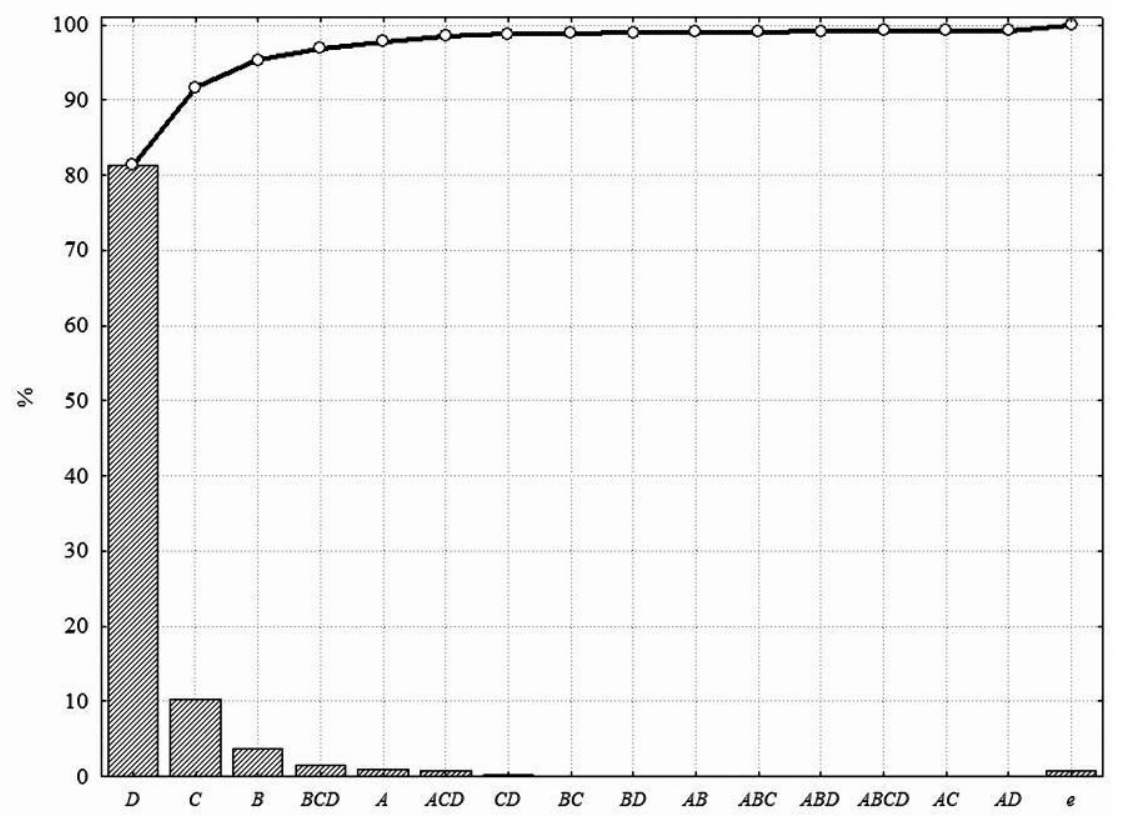

Figure 2: Adjusted Pareto diagram for contribution ratios of leg length

From Table 1 and Figure 2 it can be concluded that factor $D$ has main influence, i.e. with $81.32 \%$ influence needed space for crane cabin operators (seat height), while factor $\mathrm{C}$ (seat width) has second strongest influence with $10.29 \%$. Those two factors have effect on workspace with $91.61 \%$, with random error of $0.78 \%$.

In contrast with leg length hip breadth shows completely different results shown at Table 2 and Figure 3.
Table 2: Contribution ratios for hip breadth

\begin{tabular}{|c|c|l|c|}
\hline Effect & $\rho(\%)$ & Effect & $\rho(\%)$ \\
\hline$C$ & 25.09 & $A B C D$ & 0.97 \\
\hline$A B$ & 9.23 & $C D$ & 0.50 \\
\hline$A B C$ & 7.59 & $A C$ & 0.18 \\
\hline$A B D$ & 7.59 & $A$ & 0.15 \\
\hline$A D$ & 3.06 & $D$ & 0.15 \\
\hline$B C$ & 1.71 & $A C D$ & 0.09 \\
\hline$B D$ & 1.71 & $B C D$ & 0.03 \\
\hline$B$ & 1.31 & $e$ & 40.64 \\
\hline
\end{tabular}




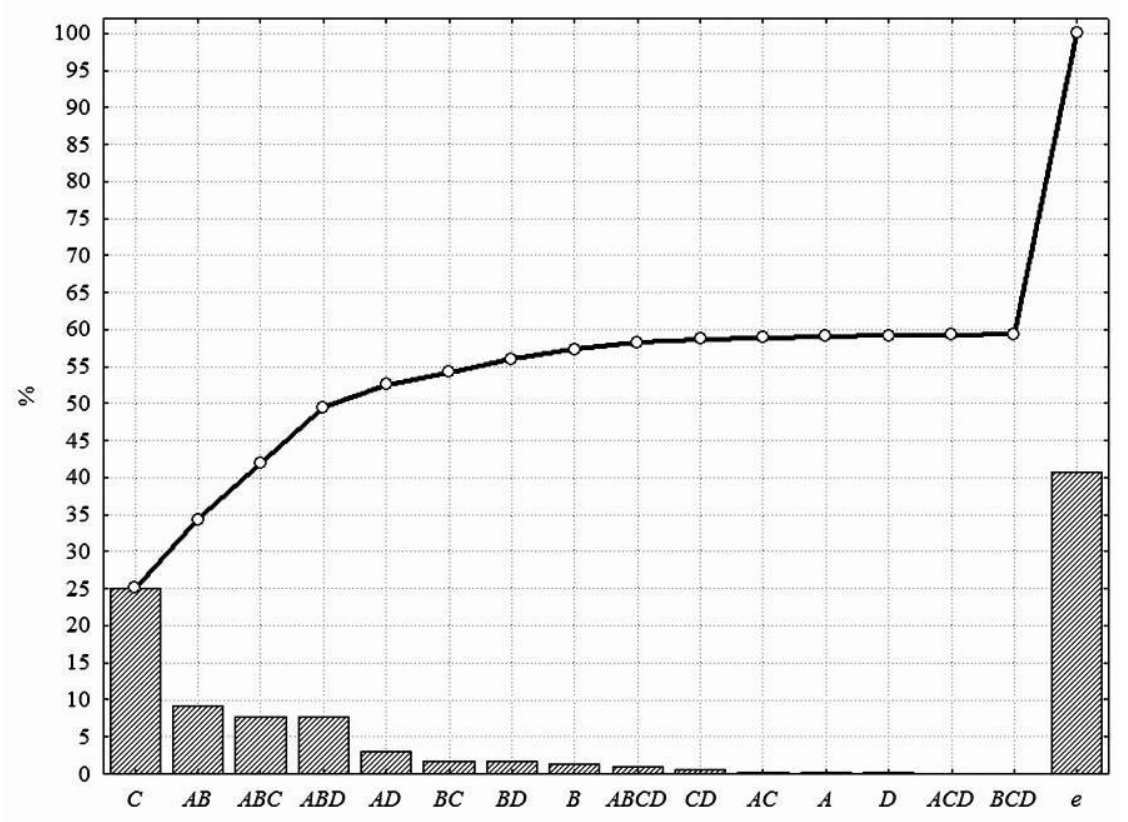

Figure 3: Adjusted Pareto diagram for contribution ratios of hip breadth

The second considered experimental result shows (Table 2 and Figure 3) that neither the factor nor their interaction has significant influence on workspace regarding hip breath (seat width has only about $25 \%$ ). On the other hand, random error has contribution ratio that equals almost $41 \%$. Therefore, the examined factors are inadequate for determination of optimal workspace for hip breath.

\section{Case study 2: Geometric deformations in optical fiber hub parts production}

In the second example, two fractional factorial designs using Taguchi's orthogonal array $L_{27}$ (three level factorials) were conducted for production of two parts for optical fiber hub. Production process was plastic injection molding. Five factors were used for construction of orthogonal array $A, B, C$, $D$ and $E$ holding pressure, injection time, cooling time, injection temperature and holding pressure time, with same factor levels and some of their interactions allocation, (Ćurić et al., 2012). Error columns are included in random errors. Parts were house and lid of optical fiber hub, (Ćurić et al., 2012; Veljković et al., 2018; Veljković et al., 2017). For both parts output geometric deformations from tree replications were measured, resulting by the production process.

Housing was constructed from Cycoloy PC/ABC Grade C2800, compound of polycarbonate and acrylonitrile-butadiene-syrane (PC/ABC) with weight $26 \mathrm{~g}$ and dimensions $155 \times 92 \times 9 \mathrm{~mm}$. The lid was constructed from Terluran, GP 35 , ABS copolymer, weighting $21 \mathrm{~g}$, width dimensions $151 \times 91 \times 1.6 \mathrm{~mm}$. There is $17.53 \%$ difference in mass and $5.84 \%$ difference in dimensions in favor of housing, (Veljković et al., 2018). The parts are presented in Figure 4.

Figure 4 also presents injection point as well as points where geometric deformations were measured. As a relevant point for discussion, in this paper, optimal geometric deformations for both parts were considered in further measurement points, where geometric deformations are the largest, (Ćurić et al., 2012; Veljković et al., 2017; Veljković et al., 2018).

For housing contribution ratios and adjusted Pareto diagram are presented in Table 3 and Figure 5.

\section{Table 3: Contribution ratios for housing}

\begin{tabular}{|c|c|}
\hline Effect & $\rho(\%)$ \\
\hline$A$ & 72.17 \\
\hline$A B$ & 6.39 \\
\hline$B$ & 4.63 \\
\hline$E$ & 2.74 \\
\hline$C$ & 1.70 \\
\hline$A D$ & 1.00 \\
\hline$A C$ & 0.80 \\
\hline$D$ & 0.39 \\
\hline$e$ & 10.19 \\
\hline
\end{tabular}




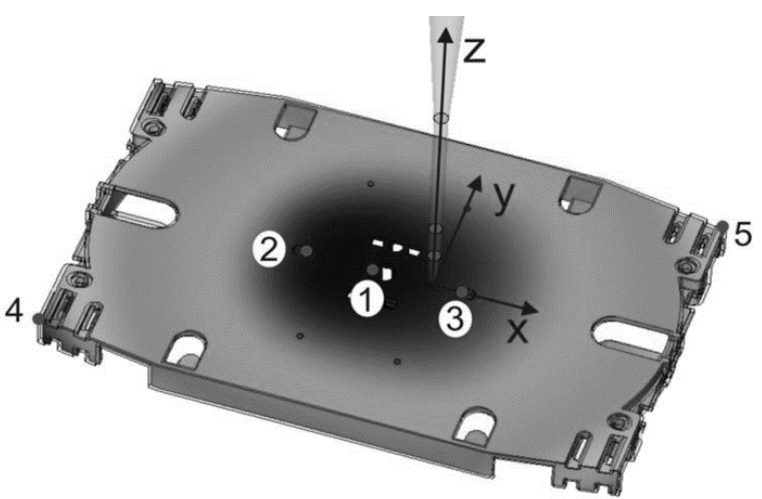

(a)

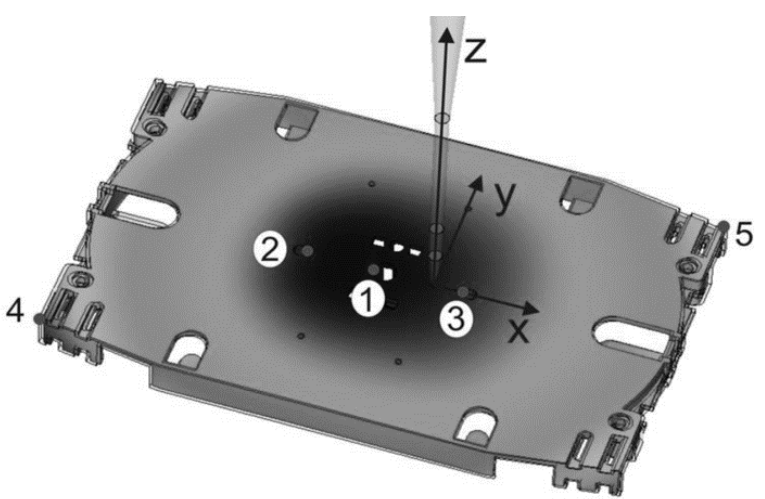

(b)

Figure 4: Housing and lid with measurement points ( Source: Veljković et al., 2018

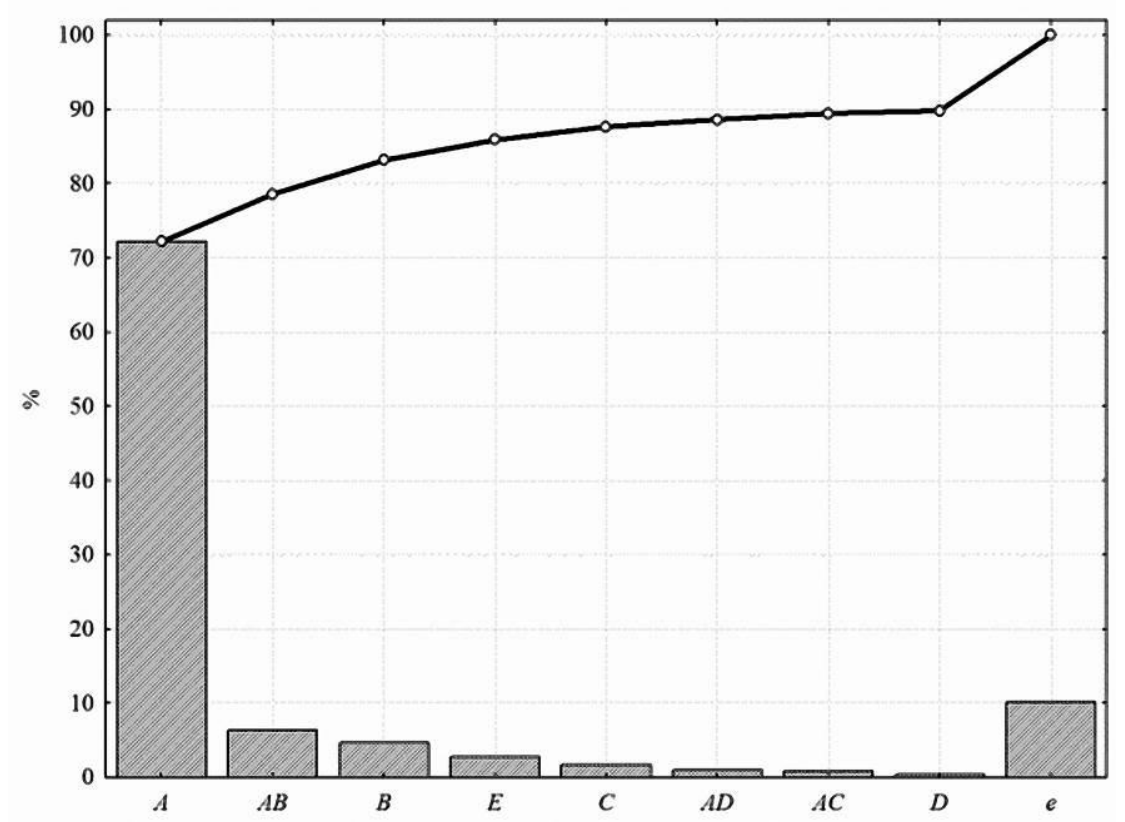

Figure 5: Adjusted Pareto diagram for contribution ratios of housing

Table 3 and Figure 5 indicate that main influence has factor $A$ holding pressure with $72.17 \%$, while factors $A$ and $B$ as well as their interaction $A B$ $83.19 \%$ have influence on geometric deformations.

In the case of lid, contribution ratios are presented in Table 4 while adjusted Pareto diagram is presented in Figure 6.
Table 3: Contribution ratios for lid

\begin{tabular}{|c|c|}
\hline Effect & $\rho(\%)$ \\
\hline$D$ & 21.34 \\
\hline$B$ & 17.53 \\
\hline$C$ & 9.79 \\
\hline$A$ & 7.30 \\
\hline$A D$ & 6.80 \\
\hline$A B$ & 6.09 \\
\hline$A C$ & 5.77 \\
\hline$E$ & 0.40 \\
\hline$e$ & 24.98 \\
\hline
\end{tabular}




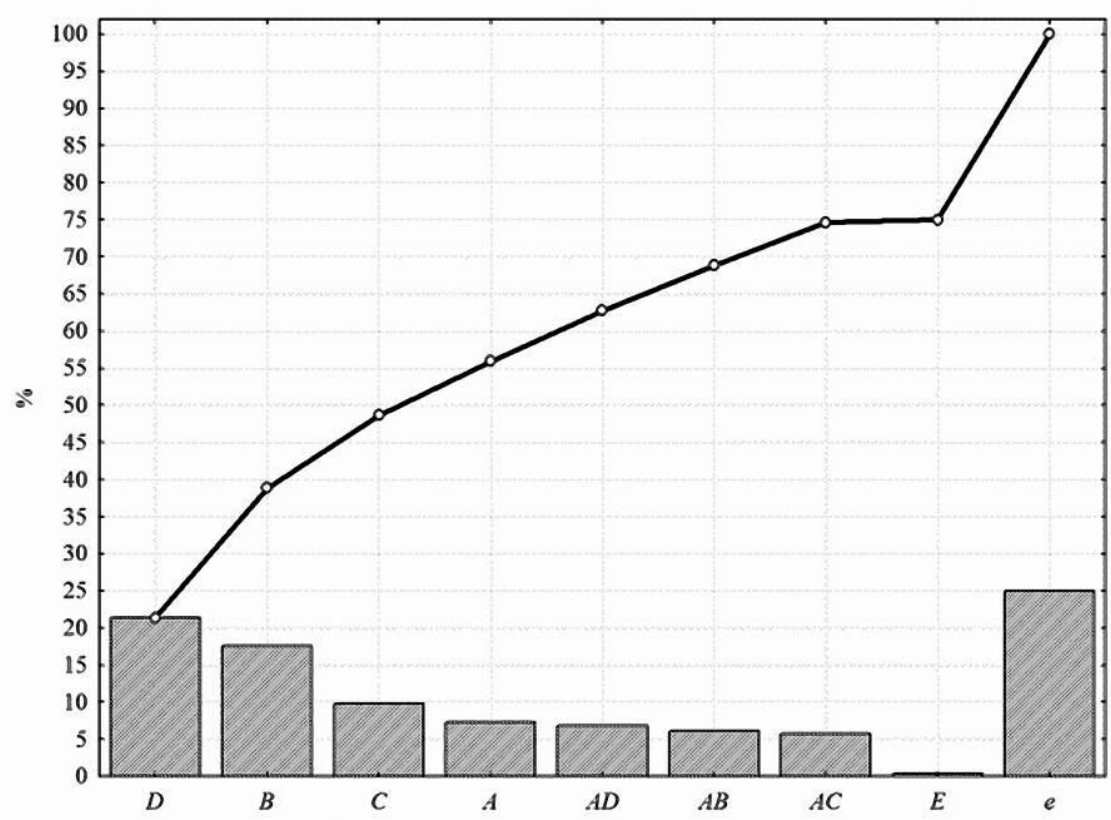

Figure 6: Adjusted Pareto diagram for contribution ratios of lid

The second experiment shows that experimental error is large, and therefore if all factors and interactions are taken into account there is no chance that they can seriously have influence on the resulting geometric deformations in the process of injection plastic molding, since injection temperature as the most important factor has only $21.34 \%$ of influence, comparing with $24.98 \%$ of random error. Therefore, other factors and their interactions or the other factor levels should be chosen in order to obtain relevant results, i.e. factors that influence geometric deformations in process.

\section{DISCUSSION}

In the first case study, one input set of factors was examined, while several output values were measured in the case of optimal workspace design for crane operators, (Spasojević-Brkić et al., 2016). Two extreme results for anthropometric measurements are shown in order to point at problems that can appear, resulting with one output value that gives usable results (first output value), and results where random error prevails.

For the second case study two different parts are examined that are produced in the same experimental conditions, i.e. with the same Taguchi's orthogonal array. Presented results emphasis on the problems that can appear with the same initial assumptions for influencing factors regardless dimensions and type of material, (Ćurić et al., 2012; Veljković et al., 2017; Veljković et al.,
2018). In the case of housing, contribution ratios are useful for determination of factor influence, while for lid experimental set-up leads to results where random errors prevail.

\section{CONCLUSIONS}

Benefits and down sides of application of factorial designed experiments or Taguchi's orthogonal arrays were presented herein. The first case study shows that for the same experiment and the same factor design, in which several different outputs were measured, the initial factor does not have the same effects on the different measurements. Therefore, in the process of designing the experiment the most important output should be appointed first and then, based on previous experiences, an experimental design, i.e. factors and their levels as well as interactions in the case of fractional factorial design should be guided by them.

The second case study shows that two different experiments with the same factors and factor levels, as well as their interactions, for production of the parts from different plastic materials and with different dimensions unlikely will lead to same conclusions of the factor influence. In other words, these are only the first experiment results along with useful results (for housing). For the lid different factors or/and factor levels should be chosen in order to obtain useful results. 
Therefore, the design of experiment, whatever method is used (traditional of Taguchi's), should be based on detailed previous research in order for experiment to be successful, i.e. experimental results to be useful.

\section{ACKNOWLEDGMENTS}

The work is supported by grants TR35017 and 174002 by MESTD

\section{REFERENCES}

Abdallah, R., Soo, S. L., \& Hood, R. (2018). A feasibility study on wire electrical discharge machining of carbon fibre reinforced plastic composites. Procedia Cirp, 77, 195-198. doi: 10.1016/j.procir.2018.08.284

Bharath, K., \& Manjunatha, G. (2018). Investigating the contribution of geometrical parameters and immersion time on fracture toughness of jute fabric composites using statistical techniques. Frattura ed Integrità Strutturale, 12(46), 14-24.

Ćurić, D., Veljković, Z., \& Duhovnik, J. (2012). Comparison of methodologies for identification of process parameters affecting geometric deviations in plastic injection molding of housing using Taguchi method. Mechanics, 18(6), 671-676. doi: 10.5755/j01.mech.18.6.3166

Derdour, F. Z., Kezzar, M., Bennis, O., \& Khochmane, L. (2018). The optimization of the operational parameters of a rotary percussive drilling machine using the Taguchi method. World Journal of Engineering, 15(1), 62-69. doi: 10.1108/WJE-032017-0067

Fratila, D., \& Caizar, C. (2011). Application of Taguchi method to selection of optimal lubrication and cutting conditions in face milling of AlMg3. Journal of Cleaner Production, 19(6-7), 640-645. doi: 10.1016/j.jclepro.2010.12.007

Ghani, J. A., Choudhury, I., \& Hassan, H. (2004). Application of Taguchi method in the optimization of end milling parameters. Journal of Materials Processing Technology, 145(1), 84-92. doi: 10.1016/S0924-0136(03)00865-3

Günay, M., \& Yücel, E. (2013). Application of Taguchi method for determining optimum surface roughness in turning of high-alloy white cast iron.

Measurement, 46(2), 913-919. doi:

10.1016/j.measurement.2012.10.013

Gunes, S., Manay, E., Senyigit, E., \& Ozceyhan, V. (2011). A Taguchi approach for optimization of design parameters in a tube with coiled wire inserts. Applied Thermal Engineering, 31(14-15), 25682577. doi: 10.1016/j.applthermaleng.2011.04.022

Islam, M. N., Rafai, N. H., \& Subramanian, S. S. (2010). An investigation into dimensional accuracy achievable in wire-cut electrical discharge machining. Paper presented at the World Congress on Engineering, London, UK.

Kurra, S., Swetha, N., Vinodh Reddy, C., \& Regalla, S. (2018). Experimental and finite element studies of single stage incremental forming process: effect of process parameters on maximum wall angle and thickness distribution. Advances in Materials and Processing Technologies, 4(2), 322-334. doi: 10.1080/2374068X.2017.1420290

Sarkar, S., Mitra, S., \& Bhattacharyya, B. (2005). Parametric analysis and optimization of wire electrical discharge machining of $\gamma$-titanium aluminide alloy. Journal of Materials Processing Technology, 159(3), 286-294. doi: 10.1016/j.jmatprotec.2004.10.009

Spasojević Brkić, V. K., Veljković, Z. A., Golubović, T., Brkić, A. D., \& Kosić Šotić, I. (2016).

Workspace design for crane cabins applying a combined traditional approach and the Taguchi method for design of experiments. International Journal of Occupational Safety and Ergonomics, 22(2), 228-240. doi:

$10.1080 / 10803548.2015 .1111713$

Taguchi, G. (1991). System of Experimental Design (Vol. 1-2). New York: Kraus.

Turgut, E., Çakmak, G., \& Yıldız, C. (2012). Optimization of the concentric heat exchanger with injector turbulators by Taguchi method. Energy conversion and management, 53(1), 268-275. doi: 10.1016/j.enconman.2011.09.011

Vankanti, V. K., \& Ganta, V. (2014). Optimization of process parameters in drilling of GFRP composite using Taguchi method. Journal of Materials Research and Technology, 3(1), 35-41. doi: 10.1016/j.jmrt.2013.10.007

Veljković, Z., Ćurić, D., \& Radojević, S. L. (2018). Mistakes in Application of Taguchi's Experimental Designs: Case Studies. Paper presented at the 7th International Symposium on Industrial Engineering SIE2018, Belgrade, Serbia.

Veljković, Z., Ćurić, D., Spasojević Brkić, V. K., \& Radojević, S. L. (2017). Determination of Quality in Plastic Injection Molding Process of Lid for Optical Fiber Hub Based on Geometric Deformations. Paper presented at the the International May Conference on Strategic Management - IMSKM17, Bor, Serbia.

Vijian, P., \& Arunachalam, V. (2007). Optimization of squeeze casting process parameters using Taguchi analysis. The International Journal of Advanced Manufacturing Technology, 33(11-12), 1122-1127. doi: 10.1007/s00170-006-0550-2

Vijian, P., \& Arunachalam, V. P. (2007). Optimization of squeeze casting process parameters using Taguchi analysis. The International Journal of Advanced Manufacturing Technology, 33(11-12), 1122-1127. 


\title{
UPOTREBA TAGUCHI-JEVOG KOEFICIJENTA UČEŠĆA I PARETO DIJAGRAMA U IDENTIFIKACIJI UTICAJNIH FAKTORA U EKSPERIMENTIMA: STUDIJE SLUČAJEVA
}

\begin{abstract}
U ovom radu se razmatra upotreba Taguchi-jevog koeficijenta učešća kao i prilagođenog Pareto dijagrama u cilju određivanja veličine uticaja projektovanih faktora u statistički planiranim eksperimentima (tradicionalnim ili Taguchi-jevim) na izlazne veličine u cilju određivanja najbolje kombinacije projektovanih fakora na posmatrane eksperimentalne rezultate u cilju dobijanja optimalnih rešenja. U radu su prikazane dve studije slučaja kod kojih svaki sadrži dva ekstremna rezultata. Prvi primer se odnosi na ispitivanje jednog ulaznog eksperimenta, podeljenog na tri manja u cilju ispitivanja projektovanog realnog, trodimenzionallnog radnog prostora kranista. $U$ ovom primeru kod projektovanog eksperimenta je mereno više izlaznih veličina. Drugi primer se odnosi na dva eksperimenta koja su postavljena na isti način ali sa različitim izlaznim veličinama. Eksperimenti se odnose na geometrijske deformacije dva različita dela razvodnika optičkih kablova koji su različitih dimenzija i izrađuju se od različitih materijala, ali istim procesom livenja plastike, pri čemu je pokazano da eksperimenti imaju različite izlazne veličine, takve da jedan daje rezultate koji su upotrebljivi u praksi, dok su rezultati drugog eksperimenta neupotrebljivi usled velike slučajne greške. Shodno tome rad daje smernice za korišćenje Taguchi-jevog koeficijenta učešća i Pareto dijagrama za efektivno određivanje uticajnih faktora i njihove veličine u oblasti planiranja eksperimenata.
\end{abstract}

Ključne reči: Planiranje eksperimentata, Taguchi-jeve ortogonalne matrice, koeficijent učešća, Pareto dijagram, Radni prostor kabine krana, Proces livenja plastike. 